\title{
A GUIDE TO THE EASIEST WAY TO HANDLE A THEORY CLASS: TECHNIQUES OF TEACHING WITHOUT CONVEYING
}

\author{
Ambarish Vijayaraghava ${ }^{1}$
}

HOW TO CITE THIS ARTICLE:

Ambarish Vijayaraghava. "A guide to the easiest way to handle a theory class: techniques of teaching without conveying". Journal of Evolution of Medical and Dental Sciences 2013; Vol2, Issue 35, September 2; Page: 6733-6735.

Modern technology provides limitless opportunities for getting recognized as a great teacher without making the least effort. Here are some useful tips on how to succeed in this game. It is a blessing that all teaching departments are expected to have LCD projector / power-point facilities (1, 2). This facility takes away the need for preparing for any class. If anyone shows curiosity regarding the way you prepare for a class, tell them confidently that you are such an expert in the subject that you need not prepare at all. You impress them that you are well prepared to enter any class and handle any lecture. However, to be successful at this game, you need to follow certain rules.

Always deliver your lectures using power point presentations. At the outset, let your students note well that you have spent a lot of your time and energy on the power-point slides as recommended by the governing council or your institution. You have to take appropriate precautions to ensure that the students do not suspect that the power-point presentation you are using is a decade old and was actually prepared by someone else. Make sure that the identity of the teacher who actually prepared the presentation is not revealed in any of the slides. You could ensure this by carefully editing the presentation so that any trace of the original teacher is erased. If the students come to know that the presentation is not your own, you are sure to lose their respect. Delete not only the name of person who prepared the presentation but also the date and other remarks that might reveal the source of the original. Remember that many teachers have a habit of putting a miniature emblem of their institution in a corner on all their slides. You need to delete such symbols meticulously from all the slides. Therefore, you do need to spend time on editing. Also, it is a good idea not to include your own name in any of the slides. You will not be embarrassed if a student accidentally discovers similar slides on the internet if the power point does not display your name. Also, students tend to remember a bad teacher for a long time and it is a good not to remind them of your own name (3).

As a rule, never use black board and chalk in your lecture, as everything you intend to say is clearly written in the slides from which you could read. You will not face the grave danger of giving original explanations (4). If you feel that students have become still and have a moon like face because they fail to follow what you are reading from the slides, show them even more of a stony face. Point out that their poise is a mark of their stupidity. Command them to copy the contents of the slides into their notebooks and tell them that they could read your remarkable explanations later if it is not clear to them in the class room. Do not allow them to sleep in the class. Never ask if you are audible to all the students. If they answer affirmatively, you may have to speak louder and waste your energy. Do not leave the dais/front portion of the lecture hall. If you do, you may not be able to read out the contents of the slides yourself. Also, you may disturb students sitting in the last rows who are usually more troublesome. It is a good policy to ignore them. Firmly believe that you are a great teacher and students have come to receive the precious gift of knowledge from your lectures. 
The more senior you are, easier it is to adopt such a strategy and you will be safer. If you are qualified to be an examiner in the university, make it clear to the students. That ensures their good behavior and they will not ask tricky questions. Also make efforts to instill the fear that they may face you in the university viva and practical exams. If you hold any administrative position in the institution or university, it is imperative that you emphasize this in class. It adds to your clout.

Do not start your class with an introduction and learning objectives. If you do, the students will expect the class to proceed along those lines and your power point file may be related to some other topic. Also do not summarize at the end. It is a waste of your time. Instead you can read out more material from the slides or narrate something else so that you are never wrong. For the same reason do not narrate historical anecdotes related to the slides, or interesting stories about inventions and discoveries connected to the lesson. You are not obliged to inspire students. It is necessary to appear at least a little intimidating. Keep a stone like face throughout the lecture. Do not be humorous; otherwise, the students might take a liking to you and might follow you after the class for discussions. Do not make any gestures either. Appear as serious and strict as possible so that students are discouraged to chase you with their doubts after the class. It is the duty of students to sit still and listen to you with rapt attention no matter how you deliver your lecture. Occasionally however, you can depart from the slides and read out from your notes. In such cases make sure that your notes are a copy of or related to the power point lecture. If any student yawns or is about to fall asleep, it is your duty to make the student stand up so that the entire class can see him/her and then reprimand him/her so that the others wake up and get the message. Never ask any questions regarding what you have taught, for you will discover that you have conveyed nothing or that your commentaries were misunderstood or worse still, that you were not audible at all. It is a good policy not to know the truth. Do not invite questions or interact during or at the end of the session. It will be more damaging to you than to the students, as you may not be able to recall what you have read out from the slides.

Be satisfied with the understanding that your time on the dais is limited and that your class gets over in an hour most of the times. It is important to know that keeping the next teacher waiting shows lack of good manners and is unethical. If you run out of your power point slides, you could always spend 10-15 minutes at the end of the class taking attendance and checking potential proxies. It is after all, a teacher's duty to ensure that the students attend the classes and maintain discipline. Note that the students are just out of adolescence and need a lot of guidance and lessons in good manners from senior teachers like you. Happily, usually there is no one to check your talent, attitude and ability most of the time. In a whole year, you may have to prepare well for only one or two classes when a supervisor visits your class for evaluation. This is an evil that you cannot avoid as a teacher. Thankfully it is only an annual ritual.

In an extreme scenario, if you feel guilty that you did not teach well or convey much, you have avenues for relief and to get out of the black mood. Please note that the students are not always receptive and you are having the freedom to imagine that you will handle the classes much better in the coming year if only the students are receptive. You can tell yourself what one of the truly great teachers said, "The students are my teachers who taught me how to teach" (5). There is always a next chance. Teaching, like learning is a never ending process. Such thoughts should suffice to lift your mood (6). Remember that there is a well known saying that people who cannot learn anymore take to teaching. It is really not so bad being a teacher (7). 


\section{REFERENCES:}

1. Lim FA. Wake up to better PowerPoint presentations. Nursing. 2012; 42 (2): 46-8.

2. Moellenberg KK, Aldridge M. Sliding away from PowerPoint: the interactive lecture. Nurse Educ. 2010; 35 (6): 268-72.

3. Pope C. No-one forgets a bad teacher. Med Educ. 2002; 36 (1): 5-6.

4. Prakash ES. How to be a bad teacher. Adv Physiol Educ. 2005; 29 (3): 182.

5. Bijlani RL, Manjunatha S. Understanding Medical Physiology. $4^{\text {th }}$ ed., New Delhi: Jaypee Brothers Medical Publishers (P) Ltd, 2011. p. i-xii.

6. Hill C. Learning in the teaching workforce. Future Child. 2007; 17 (1): 111-27.

7. Andersson C, Drumpt IV, Lagerstrom C, Ritola E. What's so bad about being a teacher? Vardfacket. 1978; 2 (6): 70-1.

\section{AUTHORS:}

1. Ambarish Vijayaraghava

\section{PARTICULARS OF CONTRIBUTORS:}

1. Associate Professor, Department of Physiology, M.S. Ramaiah Medical College, Bangalore, India.

\section{NAME ADRRESS EMAIL ID OF THE} CORRESPONDING AUTHOR:

Dr. Ambarish Vijayaraghava,

Associate Professor,

Department of Physiology,

M.S. Ramaiah Medical College,

MSR Nagar, Mattikere,

Bangalore - 560054, India.

Email-ambarishv@rediffmail.com

Date of Submission: 20/08/2013.

Date of Peer Review: 21/08/2013.

Date of Acceptance: 26/08/2013.

Date of Publishing: 29/08/2013 